\title{
Failure Recovery Management in Performance of Logistics Services in a B2B Context: A Case Study Using the 3PL Perspective
}

\author{
Luis Antonio Figueira Sanches Flores \\ Master, Propad - Post Graduate Program in the Administration/Department of Administrative Sciences of UFPE \\ lafsf@yahoo.com
}

Marcos André Mendes Primo

Propad - Post Graduate Program in the Administration/Department of Administrative Sciences of UFPE marcos.primo@ufpe.br

\begin{abstract}
What are the main factors affecting the failure recovery management in Logistics Service Providers (LSPs)? In trying to answer this question, a case study was conducted in a large Brazilian LSP to understand actions taken by that company in failure recovery processes, especially when the LSP manages business-to-business (B2B) relationships. In those situations, the LSP acts as a third party relating with other two companies in the supply chain. At the end, seven main factors were found to be relevant to the failure recovery management analysis: Strong link in the supply chain, Relationship, Level of Customer Importance, Level of Customer Importance, Procedures, Personnel Training and Technology, Rewards for performance, Outsourcing. Limitations and suggestion for future research are discussed.
\end{abstract}

KEY WORDS: Logistics services, customer service, failure recovery, B2B relationship, customer satisfaction.

\section{INTRODUCTION}

With the evolution of productive and commercial systems, companies are becoming concerned about improving quality of products/services, information timing, customized services, inventory reduction and, especially, customer satisfaction. Thus, the logistics process becomes more and more complex and with much higher levels of demands, especially when related to achieving_a competitive advantage (Christopher 2002). Bowersox et al. (2000) mention that companies that know how to efficiently integrate core competence of the supply chain are better positioned to reach/obtain better results in business and, in the process, they get a sustainable competitive advantage. With that, logistics is presented as a key factor differentiating companies in relation to supply of products and or services to customers.

Additionally, Wood Jr. (1998) says that within the essential functions of an integrated logistics structure, customer service plays a strategic role. Thus, it becomes important for companies to follow up on services offered to customers. In this aspect, failure recovery becomes one fundamental asset. According to Hart, Heskett and Sasser (1990, p.156) "Recovery is fundamental to service excellence and, therefore, should be regarded as an integral part of the service company's strategy".

Evaluating and following up failure recovery studies, we notice a focus on the final stage of the supply chain, or predominately a B2C - (Business-to-Consumer) perspective (Primo, 2003). Few studies are dedicated to management of failure recovery in the B2B - (Business-to-Business) context. This shows the need and importance of a better knowledge and understanding of the process of failure recovery management in the B2B context - which is the focus of this study. 
Besides, due to unique features of B2B relationships, this work becomes even more relevant, since it tries to contribute to a better understanding of one of the most important assets for customer satisfaction: the failure recovery process. By developing a case study, this work strives to identify the factors which influence the failure recovery management process based on the actions of a Brazilian third-party logistics service provider which receives, handles inventories and delivers products between two companies in the supply chain.

\section{REVIEW OF THE LITERATURE}

\section{Customer Service}

Customer service can be seen as one of the main goals of a logistics system and it is one of the most important areas of marketing (Stock; Lambert 1987). Customer service, in general, can improve customer relationships by three ways: (a) developing new services to be offered to the customer; (b) activating existing services or service element in a business relation c) turning the goods into a service element in the customer relationship (Gronroos 1988, p.10).

In some industries such as electronics, customer service can even be considered more important than price, sales efforts and advertising (La Londe; Zinszer 1976). Wood Jr. (1998) states that customer service is on the top of the essencial activities of integrated logistic structure, being a critical component of a business strategy. Bolumole, Knemeyer, Lambert, (2003) mention that logistics services can have a positive influence on purchase decisions, by: (a) serving as a method of building a sustainable competitive advantage, (b) increasing the likelihood of a repurchase (c) been used to secure and maintain the company customers. Among different factors which have contributed to a major role of logistics services on the companies'competitive advantage, Christopher (2002) highlights the two most important ones: (a) Constant changes in customers'desires caused by, among other things, globalization and more efficient communication, which has allowed consumers and/ or companies greater access to products and/or services; (b) Technological advances which have made products more similar, making it more difficult for consumers to tell the difference between them (commodity type markets).

One very important aspect in customer service is the understanding that requirements might be different not only among industries and companies, but also among segments of attended markets (Rushton; Oxley; Croucher 2000). Depending on market characteristics, logistics services, in general, can be classified in: (a) Standardized logistics services so all customers can be delimited by the company as having the same needs of logistics services; (b) Customized logistics services for customers that have different logistics needs; (c) Differentiated Logistics Services in which logistics services are differentiated to attend different groups of customers (Veeken; Rutten 1998).

In this direction, Bolumole, Knemeyer and Lambert (2003) go much further proposing a model for implementing a customer management process, based on the one developed by the Global Supply Chain Forum, which instead of considering customer service only from the logistics standpoint, integrates other internal functions of the company, such as other members of the supply chain. Thus, services offered by Logistics Service Providers (LSPs) have a very important role in providing value to the customer. When LSPs start being responsible for the delivery product process and/or customer service, they must do it in a way that gives a competitive advantage to specific companies, markets and/or segments, with the obligation to have a supply chain integration rather than just an internal integration.

This way, from the moment logistics services should be in accordance with a variety of services provided and needs of customers and companies, management of failure recovery must also be aligned with these parameters (customer needs, types of services provided, as well as the importance of these customers for the logistics services providers).

\section{Failure Recovery}

According to Figueiredo (1999), service recovery may be understood as a set of activities that a company performs to resolve complaints and to change the attitude of unsatisfied customers trying to keep them as loyal customers. One of the main points in the customer relationship management is how the complaint is handled. According to Hart, Heskett and Sasser (1990), complaint handling encompasses strategies companies use to solve and learn from the failures aiming to re-establish customer confidence in the organization.

As mentioned before, supply chain management, as well as logistics management, has many times been decisive in the execution of a business strategy, in 
order to offer services that create value to customers. Fleury et al. (2000), studying wholesale suppliers and retailers in the Brazilian Industry, found that failure recovery is considered by customers, the fifith most important customer service feature. Thus, it is very important to plan, follow up and evaluate the failure recovery process (key customer services attribute) throughout the supply chain and not only in the final chain stage when there is a contact with the end consumer. After all, supply chain problems, as well as logistics problems can result from many causes. By understanding the variety and interconnectedness of the supply-chain risks, managers can tailor balanced, effective risk reduction strategies for their companies (Chopra; Sodhi 2004). Despite all of that, studies on failure recovery have concentrated on the B2C context while few have discussed failure recovery in the $\mathrm{B} 2 \mathrm{~B}$ context, which could be a limitation since certain failures happening to the final consumer could have started in earlier stages of the supply chain.

Logistics services providers are in contact with at least two links of a supply chain and their efforts are very important in making products available to customers. Thus, if customer service management must be seen as a supply chain process (Bolumole; Knemeyer; Lambert 2003), failure recovery, as an integral customer service feature, must be seen in the same way.

In focusing the failure recovery process in B2B transactions, most studies assume that environmental characteristics are similar to B2C transactions. However, Primo (2003) relates several differences that affect failure and the failure recovery process in comparing B2B and B2C environments: (a) a clear difference from a supply chain perspective is that a failure can affect business and customers of the buying company. Thus a B2B failure could have a greater potential of causing damages than a B2C failure that mainly affects the immediate customer; (b) involvement of several customers, on a buying company, instead of only one customer as in a B2C transaction; (c) perception of failure and the correspondent recovery expectancy can be affected by characteristics of the relationship between supplier and the buying company, such as the interdependence level between companies and their suppliers; (d) operational features and legal and contract limits in a B2B transaction affect customer satisfaction and its evaluation of supplier performance.

Primo (2003), regarding studies on failure recovery, points out that they are related to: (a) the nature of the impact of supply failure on the customer satisfaction ; (b) expectancy of recovery on the part of the costumers; (c) customer perception of recovery activities, in light of a supply failure. It is important to point out that the impact of failure recovery, on long-term relationship components (i.e. trust and commitment) depends on past customer experiences with a company. In fact, Tax, Brown and Chandrashekaran (1998) suggested that a positive impact of failure recovery is secondary to service reliability. In other words, make sure that the service was done right the first time because this builds trust and commitment along customer history with a company. Another relevant study on failure recovery made by Tax and Brown (1998), points out four practices that together improve significantly the effectiveness of failure recovery in services, (a) hire, train and delegate; (b) establish practices and standards for recovery inservices; (c) give easy access and effective answers from call centers; (d) keep a database of customers and products.

One of the major steps in the evaluation/understanding of factors/components that affect the expectancy and perception of customer service quality was a study made by Parasuraman, Zeithaml and Berry (1988), in which a scale of 22 items was developed, and grouped into five dimensions (tangibles, reliability, responsiveness, assurance and emphaty), the so called SERVQUAL. There have been many uses of the SERVQUAL scale, in many service areas. Those authors in their study tell of some contributions/considerations for the SERVQUAL in the resale business, as follows: (a) resellers can use it to better understand customer expectancies and perceptions, and as a result, to improve services; (b) it is more valuable when used periodically to trace a tendency of service quality and when it is used together with other forms of measuring that factor; (c) it makes possible to determine the relative importance of each one of the 5 dimensions on customer quality perception; (d) it can be used to segment markets according to level of perceived quality; (e) it can be used to track the service level provided by each store in a resaler supply chain; (f) it allows comparisons of performance in relation to competitors. The importance of failure recovery may also be perceived in the evaluation of service quality being that reliability, the most important feature on the SERVQUAL scale, is defined as the capacity to supply services consistently and fast even when occur discrepancies (Parasuraman, Zeithaml and Berry, 1998). 
Several researchers have debated the insertion of items and/or dimensions in SERVQUAL, among them Bienstock, Mentzer and Bird (1997). Those authors, which developed the Physical Distribution Service Quality (PDSQ) scale, argue that logistics services B2B are offered in one context in which people are substituted by "things" and customers and suppliers are physically separated. Even so, Mentzer, Flint and Hunt (2001) considered PDSQ as only a component of a greater concept called quality of logistics services. Based on SERVQUAL and PDSQ they developed a scale/model called Logistic Service Quality (LSQ). This scale aims to evaluate/ analyze the quality of logistics services, in which 9 (nine) constructs are evaluated according to customer satisfaction with logistics services: (a) personnel contact quality, (b) order release quantities, (c) information quality, (d) ordering procedures, (e) order accuracy, (f) order conditions, (g) order quality, (h) order discrepancy handling and (i) timeliness (Mentzer; Flint; Hunt 2001).

An interesting point of the LSQ model is that several constructs, in general, converged into two constructs more directly related to customer satisfaction: timeliness and order discrepancy handling (with the exception of the constructs of personnel contact quality and ordering procedures that can also influence, directly satisfaction). Thus, it is not enough to deliver products quickly, but also you must know how to react in not foreseen situations or in case of discrepancies, since this reaction is one of the most important attribute affecting customer satisfaction.

\section{Outsourcing Logistics services}

The use of outsourcing in certain activities by companies has been growing more and more. In the last few years, companies have sought to focus their activities on core business or essential business, in which activities not considered key to their business are outsourced to specialized companies so that they both perform better in their business, and add a greater value to the customer. In this way, Hamel and Prahalad (1995 - p. 228 and 229) defined essential business: "... are the doors of future opportunities... a core business is a set of skills and technology which allow a company to offer a certain benefit to customers..." For Bowersox et al (2000, p.70), "companies that know how to efficiently integrate supply chain key businesses are better positioned to reach better results - obtaining in this process sustainable competitive advantage."
Outsourcing or subcontracting logistics services can create many benefits for the company, which ones depend on the type of company as well other circumstances surrounding that decision. According to Lynch (2004), companies can benefit by outsourcing when analyzing the following factors: pay back over resources; individual productivity; flexibility; worker relations; policy and managerial considerations; costs; customer service and specialized services; information technology; global capacity and maturity of service providers.

Further still, according to Lynch (2004) the organization should examine itself on four points related to the decision on outsourcing logistics services: (a) Is Logistics a core competence of our company? (b) If not, are we exceptionally good at it? (c) Will outsourcing add value to our logistics process? (d) Can we feel at ease with the risk of moving the control and customer relations to an outsourced company?

In order to guarantee a successful relationship that is mutually beneficial, (Lynch, 2004, p.48) proposes the use of 10 (ten) basic rules for outsourcing: (a) Develop a strategy for outsourcing; (b) Set up a rigorous provider-selection process; (c) Clearly define your expectations; (d) Develop a good contract; (e) Set up sound procedures and policies; (f) Identify and avoid potential points of friction; (g) Communicate efficiently with your logistics partner; (h) Measure performance and communicate results; (i) Motivate and reward providers; (j) Be a good partner.

Some authors call logistics services providers 3PL, or Third-party Logistics Provider. This term, according to Bask (2001, p.473) had its origins in the triad form of relationship covering the vendor, the buyer and, an outsourced logistics services provider. This triad consists of 3 double relationships, which are: the relationship between the vendor and the logistics services provider (LSP), the relationship between the buyer and the LSP and the relationship between the vendor and the buyer in the supply chain, according to Figure 1:

Figure 1 - The Three Double Relacionships Between Vendor, Buyer, Third-Party Logistics Provider.

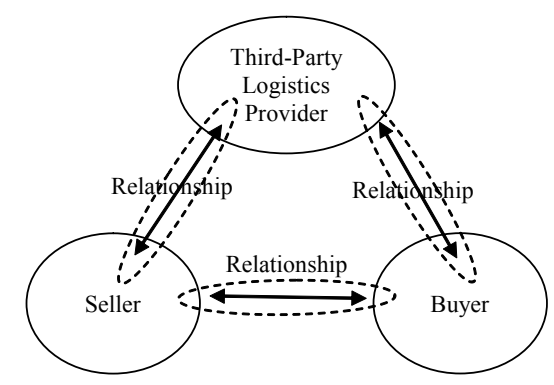

Source: Bask (2001, p.473). 
The name third-party logistics refers to a situation in which a logistics services provider acts as a third party relating to the other two parts or entities in the supply chain (Bask 2001, p.473). This way shows how the outsourcing of logistics services can affect the process of failure recovery and should be evaluated/analyzed when making the decision.

\section{METHODOLOGY}

Based on certain techniques and/or methods of development of research (Eisenhardt 1995; Merriam 1998; Yin 2001) this study was composed of the following stages up to the conclusion, according to Figure 2.

\section{Figure 2 - Stages of Study Developement}

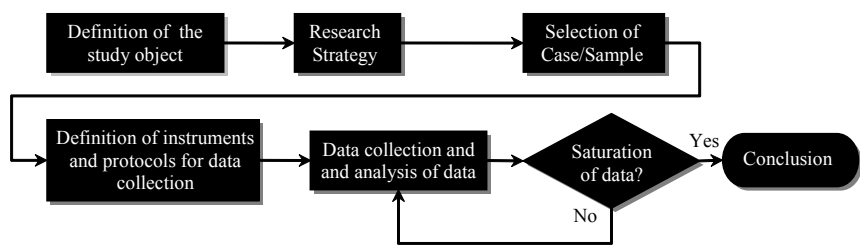

After definition of the study object, this paper utilizes a case study as its research strategy in order to reach the exploratory and qualitative nature of this research. According to Yin (2001) a case study is suitable when the research focus is on contemporary happenings or there is no need for controlling behavioral events. For the case selection, the company in analysis was chosen using criteria proposed by Merriam (1998): type, maximum variation and convenience.

A combination of multiple methods of data collection was used; interviews (semi-structured), analysis of documents, and observations, allowing triangulation between methods and/or sources, wich guarantees a better proof of information validity. The choice of interviewees was made intentionally, based on their involvement with strategic and operational issues related to failure recovery processes. The interviewees' list is: Commercial Director, Northeastern Regional Director, Insurance Manager, Call Center Manager, National Logistic Manager, Service Operations Manager, National Air Supervisor, Operational Leader and Customer Service Assistant. As to the analysis of documents and observations, one of the authors, who was part of the company staff (in activities not related to failure recovery) at the time of this study, took part in meetings/events; visited business units (Recife, São Paulo and Petrolina, for example); and got access to operational systems and performance management, training materials, service guides, as well as internet and intranet information.

Both, data collection and data analysis, were made up to the point of saturation (Merriam, 1998, p.160).

\section{Characterization of the Organization}

The organization studied in this article was given the pseudonym "LSP Company". The LSP company started with only cargo transportation and currently it has 32 business units in Brazil. Nowadays, this company is the main logistics service provider in the Brazilian North and Northeast, and also it is one of the biggest LSP in Brazil. It has more than 3 thousand employees, and attends more than 4 thousand locations in 18 states, moving close to 500 tons/ year, working close to 7 thousand active customers. Through a partnership with FedEx, it reaches around 210 countries around the world. Nowadays, this company offers logistics services, which include supply chain planning, from purchase of raw materials, production process, storage and delivery, as well as specific services in moto carrier and air transport (National and International).

\section{RESULTS}

After analysis of interviews, documents and observations, it was possible to identify and understand the main activities performed by a logistics services provider in managing failure recovery. Based on these activities, it was possible to identify the main factors of failure recovery management in that organization.

Thus, from the activities of the logistics services provider, 7 (seven) main factors were identified as the determinant ones in evaluating the recovery management of logistics failures, as described in the Figure 3. These factors are better characterized ahead, each one with a table relating some of the main findings gathered. As can be observed, some of these findings may impact/influence more than just one factor. 
Figure 3 - Evaluation Factors in the Process of Failure Recovery of a Logistics Service Provider, in The B2B context

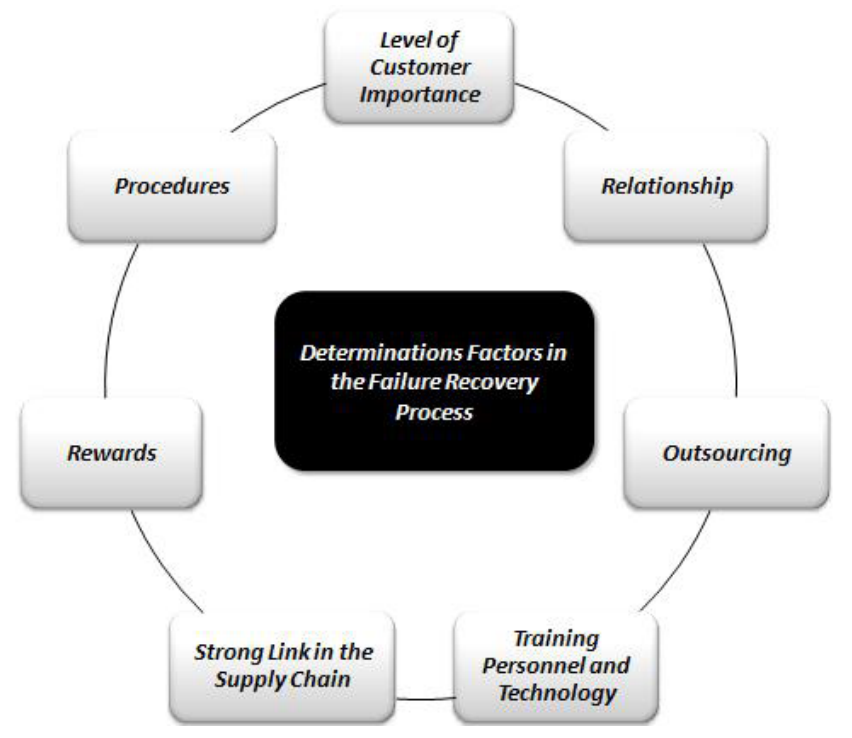

\section{Strong link in the supply chain}

The "LSP Company" did not limit its efforts only to attend companies that pay for logistics services. It was observed that the company sought to have an integrated/global vision of the failure recovery process, trying to consider not only its customer, but also companies along the supply chain. It was possible to notice, mainly, in regards to failure recovery processes, a great influence of companies which have not contracted the logistic service provider. This finding goes in the opposite direction as pointed by Bowersox and Closs (2001, p.106): "Although important conflicts can occur in a channel, few, or none of these confrontations and conflicts directly affect services providers".

Thus, it was important for the LSP to analyse in the supply chain, companies that have a greater power of decision in operational processes, as well as an influence in the choice of a logistic service provider. This analysis, besides making the processes of failure recovery easier, turned out to be a good opportunity to generate new business.

Bolumole, Knemeyer, Lambert (2003) stated that in services management, besides an internal integration, companies should develop integration with other companies along the chain. However, due to supply chain complexity, integration decision should be done by examining how important each company is in the supply chain. So, besides guaranteeing a better adjustment of the recovery process to the most relevant companies, the LSP could satisfy more customers/companies in the same supply chain.

Following, in the table 1, is a list of some of the core evidences found for this factor:

\section{Table 1 - Strong Link in The Supply Chain List Of Core Evidences}

- $\quad$ LSP Company analyzed some of the companies that had been part of the supply chain and set up a structure in the main business unit where there are large retailers, even those who are not customers, to be able to follow up and create a relationship with them. This becomes evident in the interview with the Northeastern Regional Director, as you can see in the following:

Most customers of the company are called CIF (paid at origin), something like $80 \%$; but there are customer recipients that are opinion makers and that is why they determine the rules of the game. So, it is necessary to focus on them. In the Recife unit, for example, I have an Office used only for following up three large retailers, because doing a good job for them, allows me to influence their opinion for merchandise from the same segment I work with. And they begin to indicate us... The follow up problem solving for these customers is also done by this structure, because there is another "service", with scheduling, pallets and so on... It is completely customized (Northeastern Regional Director, interview, 2005).

- Interview with the Distribution and Service Manager:

For the representative receiving customers, we have a very strong relationship. This does not matter whether or not they are the one that pays for the transportation. For example, one type of problem is to miss the delivery date of a large retailer. It was supposed to be delivered today and for some reason it could not go. If it is up to the seller who pays the transportation, the order will be canceled, but I sit down and talk with the retailer to see what can be done. According to the long-standing relationship we have, I am able to negotiate a new schedule for the delivery, sometimes the same day (Distribution and Service Manager, interview, 2005).

- Interview with the operational leader, specifically on SESEGI (Sector of Insurance and Settlements):

...When we work on the failure recovery, we do not try to find out who is to blame, but what we are going to do to satisfy the customer.

... The partnership between company and customer is the basis for minimization of problems. Through an exchange of experience we are able to implement improvements in our processes, inhibiting possible failures... (Operational Leader, interview, 2005).

- $\quad$ Something interesting noticed in the service performance, especially in shipping and handling is the special treatment that the LSP provides to companies that are not even the ones who pay for the services. We noticed this because of observations at the company, especially in the Recife unit where there was a specific structure (Office, employees and so on) to follow up on these customers. 


\section{Relationship}

The customer service structure, including call center and post-Sales, was created to keep up adequate customer relationships, according to their characteristics and importance. Also, the customer relationship mode, if active (visiting, contacts and so on) or passive (waiting and registering complaints), was a determinant factor in failure recovery processes.
Another characteristic observed is the fact that some services are performed on the customer site or on the the logistics services provider site. This trait, together with a good relationship with the companies involved, made it possible, and in most cases, easier to turn around situations of discrepancy or unforeseen in service performance, especially in making products available to the retailer.

\section{Table 2 - Relationship - List of Core Evidences}

- $\quad$ Interview with the Logistic Manager:

In performing logistics services, there is a much stronger customer relationship than the relationship of purchase/Sales of products and services to the consumer. ...When a company is buying logistic services a relationship must be developed even before signing the contract, where normally, there are biddings, preliminary evaluation documents, regions of attendance visits, presentations, and many other processes that take an average of 6 months of negotiation... Also, there are clauses that normally say that to break the contract you must give at least one month warning, among other things. (Logistic Manager, interview, 2005).

- $\quad$ Interview with the Distribution and Service Manager:

The main problems (customer fault) are: merchandise without order or order canceled and State Tax anticipated. In these cases we get contact the customer (in the case of State Tax we get in touch with the recipient - whether he is the one paying transportation or not) and many times we play the role of SEFAZ(State Secretary of Revenue), then he pays the tax and we deliver the cargo. In all other cases, contact is made with the person responsible for the shipping or his local representative. All cases are registered by automatic e-mail and then, contact is made for problem resolution. (Distribution and Services Manager, interview, 2005).

- We noticed again, that there is a need to have a relationship not only between two companies, but also with some other entities, such as the case of a relationship with SEFAZ (State Secretary of Revenue), where you need to use mechanisms of unified control.

- From what we observed at the company, there were some cases in transportation services, in which the recipient (not the one paying for shipping) of cargo services, called a business unit to make a complaint. Now in regards to other specialized logistics services (kit packing, storage, stock control, and so on), customers and/or companies also have some peculiarities. For example: most contracting companies have their own employees inside the contracted company. In other cases, it is the contracted company that is located inside the contracting company. Thus, most of the time the contracting company can see/track the logistics services provided.

- $\quad$ Another point observed was the after sales structure, which is subordinated to Commercial Managers and is responsible for following up customer operations, identifying problems with customers, new opportunities for revenue, and so on;

“... the after sales professional has as a fundamental function, to represent the shipping customer to all destinations, to check and keep constant track of quality services provided, supplying him with subsidies and also to the transportation company, aiming to maintain a good level of customer service." (Internal document of commercial procedures, 2005).

Here we noticed, as mentioned by Primo (2003) that relationships in the $\mathrm{B} 2 \mathrm{~B}$ context, have some differences from the ones in the B2C context, mainly in the following points brought up in that study: involvement of several people on the buying company side instead of a sole consumer; perception of failure and expectancy of recovery can be affected by characteristics of the buyer-supplier relationship, operational relationship characteristics and legal and contract limits. We also notice in the statement of the Distribution and Service Manager, in the table 1, that in some cases goodrelationships in the supply chain can be a differential in the resolution of certain types of problems.

\section{Level of Customer Importance}

Priorities in the failure recovery process are established according to the level of customer importance considering these customer segments: strategic, corporate and enterprise. This classification facilitates the communication process with employees, as well as the follow up and resolution of failures in services provided. 


\section{Table 3 - Level of Customer Importance List of Core Evidences}

- $\quad$ Based mainly on revenue and customer importance, this classification is extended to EDD (Estimated Date of Delivery) follow up, this being analyzed separately in, corporate, enterprise and strategic customers. The idea of this classification is that the company controls all efforts in regards to customer service; consequently, all processes and activities are prioritized for the most important customer groups: Strategic and Corporate.

- Statement of the Customer Service Manager:

Customer Service is differentiated by type of segment, degree of demand and also by customer size. For example, the customer who ships perishable products requires a more intense follow up, due to the urgency of his delivery, even if he isn't a big customer... Because each market has a level of specific demand within the segment we have a better visualization of these demands and consequently, we are able to establish levels of differentiated service.

... along general lines we provide follow up of shipping, delivery, pending orders, delivery reports of pending items, as well as feedback follow up to our system so information can be sent via EDI and also feeded on site. (Customer Service Manager, interview, 2005).

- Statement of the Insurance Manager:

The deadlines for problem solving are the same for both, strategic and corporate customers... The difference is the effort priorities for resolution of problems, where the strategic is prioritized, then the corporate, and then the enterprise customer. For example: if I visit a customer, I will give priority to a strategic customer over a corporate one. (I will leave the corporate customer for my assistant). The same situation happensif I have R $\$$ X to pay a settlement, and I have a strategic and a corporate customer: I pay the strategic customer today and tomorrow the corporate one. It is the strategy of the company and this is how we do it (Insurance Manager, interview, 2005).

- Starting with this customer classification, the company determines goals of EDD or levels of service differentiated for each group of customers, which must serve as orientation for decision-making, in case of a need for establishing priority for some customer. This was also noticed in observations taken at the company, like for example, in the Petrolina Unit, where due to the urgency and importance of a certain (strategic) customer, they establish a priority for this customer delivery, leaving other merchandise for a future delivery, (no vehicles were available).

- Besides this, from observations taken in meetings and e-mails and from following up systems of performance indicators we observed that the customer classification into three distinct groups; strategic, corporate and enterprise, was a very positive effort towards the improvement of the level of customer service follow up , allowing a differentiated customer treatment.

\section{Procedures}

It was verified the autonomy of business units and employees for payment of settlements, the way the customer contacts the company, as well as all procedures, information and flow for failure recovery processes. It was also verifiedthat company internal audits helped significantly the execution of all procedures.

\section{Table 4 - Procedure}

\section{List Of Core Evidences}

In regards to the determination of the customer service level, the Services and Distribution Manager made and interesting statement:

There is a difference between the customer service level within the same segment. In fact, each case is a different one. ...The cargo profile has one characteristic in common, but the operation usually isn't the same. It diverges even in the procedure of checking. For example, with a certain customer, it is checked according to the order, but with another customer from Campinas, it is done according to the invoice (Manager of Distribution and Services, interview, 2005).

There is, also in all units of the company, an area or sector reserved for problem solving, be it a shipping problem or a specialized logistics service one. This area, called "Solutions" (before called "Pending items)", is responsible for problem solving and/or interacting with customers in the case of: failure, surplus, damaged cargo, cargo retained for STATE TAX, returns, special procedures for customer, damages and so on. If there is any problem at a service provision, for example, the merchandise was confiscated by SEFAZ (State Tax Service) or when something is missing or damaged while loading of discharging merchandise, there is a specific place in the area of Solutions to deal with that, and that area interacts with other units or even with the customer to solve the problem.

When some problem happens and the cause of the problem was related to the loading of the merchandise, the pending items area gets in touch with the unit of origin to find a solution for the problem. In these cases, the unit is instructed to take pictures of how the merchandise arrived in the destination unit, so it can be checked and find a solution to the problem. Even if it didn't cause a loss to the company (Insurance Manager, 2005).

One procedure between the LSP and their customers to improve the process of failure recovery, specifically in providing shipping services (delivery) is the use of a "return password". This password is used when for some reason the delivery cannot be made.

Another important factor for customer service and, consequently, for the process of failure recovery is the establishment of deadlines for call center responses to customers, which are described as following (LSP , Company Guide of Services 2004, p.15):

Maximum time of response of information to customers: 12 hours; Maximum time of return for customer complaints: 24hours;

Maximum time of reimbursement of Failure: 15 working days after receipt of Invoice;

Maximum time of reimbursement of damage: according to due date of invoice;

Maximum time of response to e-mail or letter: 24hours;

Time of response of proof of delivery: deadline of delivery +5 days;

\section{Personnel Training and Technology}

Investments in training also help the failure recovery process, either by retraining and/or additional instruction of employees. Investments in technology in the operational area are important actions helping the failure recovery process. This type of effort, besides reducing the possibility of human error, in some cases can eliminate the possibility of failure re incidence. 


\section{Table 5 - Personnel Training And Tecnology List Of Core Evidences}

Statement of the Northeast Regional Director:

A study made with customers showed two points of complaint: a) speed of information and b) proof of delivery. To solve the problem of speed of information, M4U was created. Just what is M4U? Information on-line. I have cases here, where the customer filed a complaint and I am informing him on-line, ("just in time"). The digital file is also a proof that we work with results of the research, because the customer now has within minutes access to proof of delivery, (Northeastern Regional Director, interview, 2005).

Statement of the Distribution and Services Manager:

In the main forwarding stations we have exchanged information via EDI about each event of the operation. ...When the customer calls, we know where the cargo is and what has happened to it, even if we don't have it in our possession. However, in some units this process is more advanced than in others.

... One problem we have had was the merchandise delivery slip, because the slip is the legal proof and without it we cannot invoice and we have been sued for this. An alternative we found was the creation of a digital file, where our proof of deliverys is digitalized. (Manager of Distribution and Services, interview, 2005).

Within the different efforts for the development of intelectual capital of the company, some of the highlights are: the Project "Educate" and Training of Operational Leaders.

In regards to the Project "Educate" it seeks to improve the level of education and training of employees, especially the operational base. Following are some excerpts from the article that the LSP made available by NetMarinha, in celebrating 5 years of the project in 2002:

During that period, close to 500 employees attended programs of reading and writing and reinforcements of middle school, and high school.

...The courses are provided by the company, using teachers who work with SESI and or CIEE, and try to correct distortions caused by the lack of schooling. The goal is to reach $100 \%$ of the employees who fit this profile, in all business units around the country.... Half of the resources destined to the personnel sector are invested in projects and programs directed to the operational area, with a turnover rate of almost zero. Among the benefits, there are awards of scholarships at universities, college prep courses and other specialization courses that are important for employee training (NETMARINHA, 2002).

In the leader training, with a projected duration of 230 hours, employees receive information about behavior, information, customer assistance, types of vehicles, legal documentation, handling, packaging, symbology and operations of main services and segments attended by the company.

Besides these efforts, the company has taken some executives for visits to the head Office of the American company FEDEX, in Memphis (USA), to see close up how one of the main companies in the business performs, as well as promoting growth/learning of their professionals. However, an important statement from the Comercial Director, regarding the perception of technological evolution of the company was: "The technology of the company is its people." (Flores; Lucena; Primo 2004).

Another important point was, a database of the company, with all of the complaints for each customer, and how long he took to be attended, re-incidence, and so on.

\section{Rewards for performance:}

The inclusion of quality as well as failure recovery indicators in the company rewarding model also helped to improve and to develop failure recovery efforts. When employees' payment is affected by performance of these indicators, their focus becomes greater, as well as their concern with performance improvement.

\section{Table 6 - Rewards For Performance List of Core Evidences}

From some evidences, such as analysis of documents (reports from performance systems indicators- Cockpit) and observations (participation in directors' meetings) it was possible to verify (based on variable payments and/or rewards from the year 2005) that among the 17 (seventeen) indicators used for rewards, at least 8 are directly related to quality of services. Those indicators are:

EDD (Estimated Date of Delivery) - the percentage of deliveries made on time is measured by all company as well as by customer segments: Strategic, Corporative and Enterprise;

$\%$ of Solution to Problems - refers to percentage of problems solved within a certain period;

Time of Response to a Request - average time spent by a business unit for providing information requested by customer and/or by the call center (cells of information or special attendants);

Time of Response to a Complaint - similarly to the former, it refers to average response time to a complaint;

Information Release Performance - the percentage of information on delivery of merchandisereleased within a certain period (for example: 0(zero) days, 1 (one) day, and so on);

$\%$ of Problems in Delivery, When the Company is at Fault-number of instances and/or problems in delivery when the company is at fault;

$\%$ of Instances of Missing - percentage of merchandise missings;

$\%$ of Instances of Damage - percentage of merchandise damages.

Another factor observed, was an increase in the policy of payment to third parties for produtivity and efficiency in delivery. However, no program and/or effort regarding reward and/or recognition of the best companies subcontracted was verified in the LSP, contrary to some big companies that contract logistics services in Brazil, such as Gillete, Volvo, among others.

An important aspect in the evaluation of those indicators is that some of them are evaluated on a corporate level. The company believes that, at first thought, it is more advantageous for the business units working together to improve overall performance. For example, part of EDD (payment reward) is is evaluated from the overall results of the company, independently on the business unit performance. However, operationally, the company also makes an evaluation of EDD by destination and origin so that corrections can be made to improve business unit performance. This becomes very relevant for logistics operations, since interdependency of the business units for a LSP is in some cases, much greater 
that the one found in companies from other segments/markets.

\section{Outsourcing:}

By outsourcing certain activities, the company created mechanisms of control and communication of these activities, even in regards to information, procedures, technology and rules for failure recovery.

\section{Table 7}

\section{Outsourcing - List of Core Evidences}

Presently, the company, besides using their own vehicles for transfer and distribution of products, also subcontract third party services. This situation requires specific tracking and follow up, in contracting both air and land distribution services. The National Air Supervisor provided an interesting statement on this aspect from when he talked about the problem of using third parties (airlines), the serice quality, as well as the process of negotiation:

At the moment, in air services there should be a standard and the customer should try to adjust to it. Nowadays, one of the problems you run into in providing air services is the excess of customization required by some customers; this happens when you do not own the main resource of the service chain - the airplane. This does not mean that I am against customization for customers, but I think that the customer should listen more to the company since it is in the "production chain" (National Air Supervisor, interview, 2005).

To solve this kind of problem, the LSP has sought to maintain a good relationship with the airline companies. One example of the importance of the relationship with the air lines was verified in a General Meeting, with all LSP executives in 2005. In that meeting the Regional Air Manager asked the unit Managers to put forth more effort in the relationship with the airlines, because this could help solving problems, getting flexibility and/or priority in the execution of some efforts.

Besides, in the performance of shipping services, the company has a structure for following up incidents together with subcontracted companies, according to the following statements:

Today, due to the need for partnerships to cover $100 \%$ of Brazil, we have a team to track all operations of subcontracted services. This team is responsible for measuring the number of incidents and the values of these incidents, and even for training the partner to work correctly with our customers (Operational Leader, interview, 2005).

Besides, we have some people in certain busisness units whose only responsibility is to analyze/track the forwarder performance. When there is some kind of problem with the forwarders, we visit the companies (forwarders) checking what is in the contract, and so on. (Distribution and Service Manager, interview, 2005)

Additionally, it was observed that in the company, specifically with regards to strategic alliances with Mercúrio and Expresso Araçatuba shippers (Brazil Alliance), there is a space in the headquarter office just for tracking these things, checking fees charged and received, discounts given or required, and so on.

At the end of 2005 an internal customer satisfaction survey revealed an improvement of $3 \%$ in customer perceptions in regards to solution of problems (in a sample of 285 customers), compared to the year before. Also, service quality results in 2007 were rewarded by some of company leading customers:

- Motorola - Best provider of logistics services;

- Natura - Certificate of Operational Excellency, for the second year in a row;

- Semp Toshiba - Best supplier of land and sea shipping.

\section{CONCLUSION}

From this study, it was possible to identify 7 (seven) factors that should be evaluated for the management of failure recovery in logistics services. They are: strong link in the supply chain, relationship, level of customer importance, procedures, training and technology, rewards according to quality indicators, and outsourcing. From the practical standpoint, hopefully the understanding of the main efforts of the logistics service provider and especially, the analysis of those factors can help other LSPs to define efforts and/or structures necessary for the failure recovery management. Since distances between companies are decreasing and business partnerships are more and more usual, it is important to have a better understanding of how companies deal with failures in the distribution of products/services. Also, case studies may help other companies setting up their procedures on the failure recovery management.

From the academic standpoint, due to lack of literature on failure recovery management in the $\mathrm{B} 2 \mathrm{~B}$ perspective, and the lack of knowledge on how failure recovery management can affect the supply chain performance, this topic should be given a lot of attention and care, on the part of researchers and companies providing logistics and/or supply chain services. Failure recovery is still a vast field for investigation that affects the LSP credibility with customers, which is a necessary condition in logistics activities.

\section{Limitations and suggestions for future studies}

This study has an exploratory and descriptive nature which brings the following limitations, as well as suggestions for future studies:

- Limitations: (a) Data analysis and interpretation were based on the knowledge and subjectivity of one of the authors who has professional experience in the area; (b) There was no survey and/or 
interview with the LSP customers to evaluate the performance of the company in failure recovery processes. In this aspect, the evaluation obtained was the improvement of customer perceptions as regards to resolution of problems, by the customer satisfaction survey conducted by the company. This survey showed an increase of $3 \%$ on this attribute. Also, the LSP has been rewarded on this issue by three of its large customers (Motorola, Natura and Semp Toshiba).

- Suggestions for future studies: (a) Some studies may focus the limitations of this study. For instance, a study where there is an analysis of the recovery process all along the supply chain could answer many questions related to problems and/ or difficulties that companies have faced, including suppliers and buying companies; (b) Elaboration of quantitative studies, which could allow information gathering all along the supply chain and facilitate statistical generalizations about failure recovery management factors.

\section{Managerial Implications}

The factors brought up in this study may help companies to define their recovery management policies for logistics failures. Thus, managers can try to find the degree of influence these factors have on recovery of logistics failures, and define better customer service policies.

\section{REFERENCES}

Africk, M. Jon. and CALKINS, S. Caroline (1994), "Does asset ownership mean better service?" Transportation \& Distribution, May.

Ballou, Ronald H. (1993), “Logistics Enterprise: shipping, administration of materials and physical distribution", São Paulo: Atlas.

Bask, Anu H. (2001), "Relationship among TPL providers and members of supply chain - a strategic perspective," The Journal of Business $\mathcal{E}$ Industrial Marketing, v. 16. i.6, p.470-486.

Bienstock, Carol, Mentzer, John, and Bird, Monroe Murphy (1997), "Measuring Physical Distribution Service Quality", Journal of Academy of Marketing Science, v.25, i.1, winter.

Bitner, M.J., Booms, B., and Tetreault, S.M. (1990), "The service encounters diagnosing favorable and unfavorable incidents," Journal of Marketing. v. 54. p.71-84, January.

Bolumole, Yemisi A., Knemeyer, A. Michael, and Lambert, Douglas M. (2003), “The customer service management process", The International Journal of Logistics Management.v.14. i.2. p.15-31.
Bowersox, J. Donald., and Closs, J. David (2001), Logistics enterprise: the process de integration of the supply chain", São Paulo: Atlas.

Bowersox, J. Donald., Closs, J. David., Stank P. Theodore, and Keller, B. Scott (2000), "How Supply Chain Competency leads to business success", Supply Chain Management Review, September.

Chopra, Sunil, and Sodhi, S. ManMohan (2004), "Managing Risk to Avoid Supply-Chain Breakdown", MIT Sloan Management Review. Fall.

Christopher, Martin (2002), Logistics and Management of the Supply chain: strategies for redution of costs and improvement of services, São Paulo: Pioneira.

Eisenhardt, K. (1995), "Building theories form case study research", In: Huber, G.; Van de Ven, A. (org). Longitudinal field research methods: studying processes of organization change. Thousand oaks: Sage, p. 65-90.

Fleury, Paulo .F. and Silva, César. R. (2000), “Evaluation of service of physical distribution: relationship between the consumer goods industry and wholesale and retail commerce", In Fleury, P. F., Wanke, P, and Figueiredo, K. Logistics Enterprise: the Brazilian Perspective, 1‥ Edition, São Paulo, Atlas, p.76-92.

Figueiredo, Kleber (1994), “The Recovery of Logistics Services: how companies should act when they make mistakes and how to change behavior of unsatisfied customers in order to keep the customers", Available at: $<h t t p: / / w w w . c e l . c o p p e a d$. ufrj.br>. Accessed: October $3^{\text {rd }} 2004$.

Flores, Luis A. F. S., Lucena, Eduardo, and Primo, Marcos (2004), "Development of Competitive Resources: The Case of the “Company LSP" ". Propad, UFPE (not published).

Gronroos, Christian (1988), "New Competition in the Service Economy: the five rules of service", International Journal of Operations \& Production Management, p.9-19.

Hart, W.L. Christopher, Heskett, L. James, and Sasser, W.E.Jr. (1990), "The Profit Art of Service Recovery", Harvard Business Review. July-August, p.148-156,

LaLonde, B.J. and Zinszer, P.H. (1976), “Customer Service: Meaning and Measurement", National Council of Physical Distribution Management, Chicago, IL.

Lynch, F. Clifford (2004), “Why Outsource?", Supply Chain Management Review. October, p.44.

Mentzer, J. T., Flint, D.J., and Hult, T.M. (2001), “Logistics service quality as a segment-customized process", Journal of Marketing. v.65. October.

Merriam, S. (1998), "Case studies as qualitative research" In.: Qualitative research and case study applications in education, San Francisco. Jossey-Bass, p.34.

Netmarinha (2004), "Project "Educate"", Available at: <www.netmarinha.com.br>. Accessed: October 23.

Parasuraman, A., Zeithaml, V., and Berry L. (1998), “SERVQUAL: a multiple-item scale for measuring consumer perceptions of service quality", Journal of Retailing. v.64. Spring. 
Flores, L. A. F. S. and Primo M. A. M.: Failure Recovery Management in Performance of Logistics Services in a B2B Context: A Case Study Using the 3PL Perspective Journal of Operations and Supply Chain Management 1(1), pp.29-40, (C) International Conference of the Production and Operations Management Society

Prahalad, C. and Hamel, G. (1990), “The core competence of the corporation", Harvard Business Review, v.68, i.3, p.79,91, May/ Jun.

Primo, Marcos André Mendes (2003), "Supply Failure and recovery Incidents in Business-to-Business Exchanges". Doctoral Dissertation - Arizona State University, EUA.

“Company LSP" (2004), Guide of Services, Volume II. Maio.

“Company LSP" (2004), Training Operational Leaders.

“Company LSP" (2004), Institutional Site. available at <http:// www."companylsp".com.br>. Accessed: October 23.

Revista Log \& Mam: Logistics, handling and storage of materials (2005),"Specialization as a weapon to expand business", São Paulo: Instituto IMAM, n. 172, Jan.

Rushton, Alan, Oxley, John, and Croucher, Phil (2000), The Handbook of Logistics and Distribution Management, Second Edition, The Institute of Logistics and Transport. UK: Kogan Page.

Stock, J.R. and Lambert, D.M. (1987), Strategic Logistics Management, 2nd ed., Irwin, Homewood, IL.
Tax, S. S., Brown, S.W., and Chandrashekaran, M. (1998), “Customer Evaluations of service complaints experiences: implications for relationship marketing". Journal of Marketing. v.62. p. 60-76. April.

TAX, S. Stephen., BROWN, W. Stephen (1998), "Recovery and Learning from Service Failure", Sloan Management Review. Fall, p. 75-88, 1998.

Veeken, J.M. Danielle van der, and Rutten, G.M.M. Werner (1998), "Logistics service management: Opportunities for differentiation", International Journal of Logistics Management. Ponte Vedra Beach: v.9, i.2, p.91-98 (8 pp.).

Wood Jr., Thomas (1998), "A Strategic Approach to company Logistics", EAESP / FGV / NPP - Núcleo de Pesquisas e Publicaçoes. Report of Study n.5.

Yin, R. (2001), Case Study: planning and methods. 2. edition. Porto Alegre: Bookman.

\section{Author's BIOGRAPHY}

Luis Antonio Figueira Sanches Flores - Masters in Administration, area of concentration Supply Chain Management, at UFPE - Federal University of Pernambuco. Experience in the areas of Strategic Management, Supply Chain Management and Information Technology. Professor Boa Viagem College, also a consultant in the area of Strategy and Logistics. Areas of interest: Supply Chain Management, Company Strategy and Information Technology.

Marcos André Mendes Primo - Ph.D. in SUPPLY CHAIN MANAGEMENT - ARIZONA STATE UNIVERSITY. Professor adjunto of the Federal University of Pernambuco, presently coordinator of supply chain and logistics management GOL-B of Anpad, vice-coordinator of Post-Graduation Program (Propad/UFPE), executive editor of electronic management magazine GESTÃO.ORG. Coordinator of research center GIRO (Management of Innovation in Operations Networks). Has done research on naval industry, logistics services and information/telecommunications technology. 